\title{
Women's Changing Opportunities and Aspirations Amid Male Outmigration: Insights from Makueni County, Kenya
}

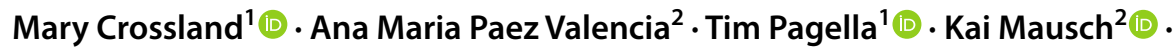 \\ Dave Harris $^{1,3} \cdot$ Luke Dilley $^{2,4} \cdot$ Leigh Winowiecki ${ }^{2}(\mathbb{0}$
}

Accepted: 16 January 2021 / Published online: 15 February 2021

(c) The Author(s) 2021

\begin{abstract}
In Makueni County, Kenya, an area experiencing intensifying migration flows, we investigate the aspired futures of rural men and women using a novel methodology combining a narrative-based survey tool, focus group discussions and semistructured interviews. Our findings indicate that, in the absence of men and presence of norms restricting women's movement out of rural life, women are becoming increasingly engaged in farm management. Women's aspirational narratives focused on commercialising farm activities, likely reflecting their changing agricultural opportunity space and new realities as farm managers. We highlight that only considering aspirations at the household level overlooks differing individual contributions, agency over various household income streams and individuals' changing roles throughout life. Based on our findings, we make recommendations for further aspirations research including explicit consideration of intrahousehold heterogeneity and how individual strategies and aspirations interrelate and are negotiated at the household level to build an overall livelihood strategy.
\end{abstract}

Keywords Smallholder agriculture · Agency $\cdot$ Gender relations $\cdot$ Generation . Intrahousehold dynamics $\cdot$ Livelihood strategies $\cdot$ Feminisation

\section{Résumé}

Dans le comté de Makueni, au Kenya, une région où les flux migratoires s'intensifient, nous étudions les aspirations des hommes et des femmes en milieu rural à l'aide d'une nouvelle méthodologie qui combine un outil d'enquête basé sur la narration, des discussions de groupe et des entretiens semi-directifs. Nos résultats indiquent

Mary Crossland

afp43d@bangor.ac.uk

1 School of Natural Sciences, Bangor University, Bangor, UK

2 World Agroforestry (ICRAF), Nairobi, Kenya

3 International Crops Research Institute for the Semi-Arid Tropics (ICRISAT), Nairobi, Kenya

4 Akita International University, Akita, Japan 
qu'en l'absence d'homme, et lorsqu'il existe des normes qui restreignent les mouvements des femmes hors de la vie rurale, les femmes sont de plus en plus impliquées dans la gestion des entreprises agricoles. Le récit des aspirations des femmes est concentré sur la commercialisation des activités agricoles, ce qui reflète probablement l'évolution de leur champ d'opportunité agricoles et leur nouvelle réalité en tant que gestionnaires agricoles. Nous soulignons le fait qu'en considérant les aspirations uniquement au niveau des ménages, on néglige les contributions individuelles divergentes, le contrôle des divers flux de revenus des ménages et l'évolution des rôles des individus tout au long de la vie. Au vu de nos résultats, nous recommandons des études complémentaires sur les aspirations, avec une prise en compte explicite de l'hétérogénéité au sein des ménages et de la manière dont les stratégies et les aspirations individuelles interagissent et sont négociées au niveau des ménages pour construire une stratégie globale de subsistance.

\section{Introduction}

Developing and scaling new agricultural technologies is widely considered an essential pathway for increasing the productivity of smallholder agriculture in lowincome countries and to achieving the UN's Sustainable Development Goals of ending poverty and hunger (Pingali et al. 2006; Vorley et al. 2012). Yet, despite significant investment from governments, researchers and international development agencies, changes in agricultural practices over the past decade have been slow (Thornton et al. 2018), with numerous cases of low adoption by smallholder farmers of seemingly productive and profitable technologies (e.g. Arslan et al. 2013; Chirwa 2005; Walker and Alwang 2015).

Development-focused agricultural researchers have paid considerable attention to identifying the factors that constrain or enable the uptake of new innovations, resulting in an extensive list of adoption-related variables (Feder et al. 1985; Mwangi and Kariuki 2015). These tend to centre on observable characteristics such as a farmer's access to information, markets and complementary inputs and resources, including land, labour, capital and credit. Less attention, however, has been paid to internal factors that drive adoption decisions, such as a farmer's attitudes, preferences and motivations. Even when such factors are considered, they are rarely understood in the broader livelihood context that, for many smallholder households, often includes non-agricultural components.

Given the seasonal, risky nature of farming, the inherent limitations of small farm size and the prevalence of severe land degradation, rural households in sub-Saharan Africa rarely rely on farming alone and increasingly pursue diverse livelihood strategies comprising various on- and off-farm activities and income streams in order to survive (Barrett et al. 2001; Harris and Orr 2014). Consequently, decisions over resource allocation and investment often involve complex trade-offs between multiple livelihood activities (Giller et al. 2006). While households may derive part of their livelihood from farming and personally identify as farmers, agricultural production is unlikely to be the only aspect of their livelihood portfolio they are seeking 
to maximise. Indeed, many households may seek to step out of farming completely and focus on local or migratory off-farm income sources (Dorward et al. 2009).

In recognition that people's desired futures likely play an important role in influencing their investment decisions, there is a small yet growing literature arguing for greater consideration of livelihood aspirations ${ }^{1}$ in the design and targeting of development-focused agricultural research (Dorward et al. 2009; Mausch et al. 2018; Verkaart et al. 2018). Both Mausch et al. (2018) and Verkaart et al. (2018) contend that, in addition to current livelihood portfolios, an understanding of people's aspired livelihood activities could inform a more targeted and efficient approach to rural development.

Through understanding people's current situations, desired trajectories and the influences that shape these aspirations, researchers and development actors might tailor support options ${ }^{2}$ to better meet the needs of different user groups by matching technologies to peoples' strategies and demands (Mausch et al. 2018). For example, within the Dorward et al. (2009) framework, people who see farming as their main occupation and aspire to 'step up' their farming activities are likely to be more willing to invest in longer-term and/or more financially intensive options, such as agroforestry, land restoration or irrigation technologies. Innovations around markets and commercialisation are also likely to be better received. For those who do not see a future in farming and want to 'step out' and pursue non-farm income sources or even migrate to urban areas, labour-saving agricultural technologies, loans and training in non-farm skills may be more appropriate. For those who are net buyers of staple food crops and lack alternative options to farming or still hope to be able to 'step up' at some point and are therefore 'hanging in', agriculture could provide an important safety-net. Given their lack of resources, innovations aimed towards social protection and food security (e.g. providing inputs such as seeds, food assistance or lowcost innovations) are likely to be important for this group. Understanding people's current circumstances and livelihood aspirations could enable agricultural research and development initiatives to better serve the wants and needs of rural populations.

This is not to say that agricultural research and development do not have a role in addressing the underlying causes for farmers choosing to 'step out' and divest from farming. For example, in addressing low agricultural productivity and land degradation which undermine a household's ability to generate returns beyond the poverty line. Nevertheless, focusing efforts on areas and groups where they are potentially most valuable and appreciated is likely to make better use of limited resources and, ultimately, have greater impact on poverty and food security (Gassner et al. 2019).

\footnotetext{
1 While aspirations-based theories in economics have largely focused on people's 'capacity to aspire' (Appadurai, 2004), or rather their level of ambition relative to those around them, we use the term 'aspiration' to refer to what people aspire to do, with specific attention to the livelihood activities with which they wish to engage (Mausch et al. 2018).

2 Although systems of innovation emerge from different and often interrelated forms of knowledge (Glover et al. 2019), our focus in this study is the role of aspirations within processes of technological change driven by external institutions, rather than those arising from farmers' own experimentation and experience.
} 
The concept of 'opportunity spaces' has recently been used to conceptualise the formation of aspirations (Elias et al. 2018; Rietveld et al. 2020). An 'opportunity space', as defined by Sumberg et al. (2012:5), is "the spatial and temporal distribution of the universe of more or less viable options that a young person may exploit as she/he attempts to establish an independent life". The topology of a person's opportunity space is first a function of the physical realities in which they live and includes climate, geography and market availability. A person's ability to explore and exploit this space is then further mediated by social factors including social identity, norms and relations (Sumberg and Okali 2013). Age and gender are important and intersecting social dimensions in structuring people's position in society, their access to, and control of, agricultural assets and resources and thus men's and women's livelihood possibilities throughout life (Meinzen-Dick et al. 2012). Yet, recent studies on rural aspirations in relation to agriculture have largely focused on the aspirations of young men and women (e.g. Elias et al. 2018; Rietveld et al. 2020) or overlooked gender and position in household completely (e.g. Verkaart et al. 2018). In this preliminary study, we attempt to shed light on the role of intrahousehold dynamics in shaping men's and women's opportunity spaces and aspirations and how they evolve throughout life.

Consideration of the intrahousehold relations that underpin men's and women's livelihood strategies and aspirations are increasingly pertinent with intensifying migration trends across sub-Saharan Africa. Where local labour markets are inadequate and farms insufficient in size and quality to ensure a reliable livelihood, household members seek to diversify their income streams through migratory wage labour, leaving their homesteads for extended periods of time (Mercandalli et al. 2020). Due to economic and social factors, these mobilities are often gender-specific, with male household members often being those who leave (Chant and Radcliffe 1992). Resultant changes in household structures can lead to redistribution and redefinition of household responsibilities, with women often assuming the role of primary farmer (Yabiku et al. 2010). This reconfiguration of responsibilities can increase both the physical and emotional burden on women, but equally give women greater agency over household and farming decisions in ways that allow them to further their wants and needs (Saha et al. 2018; Slavchevska et al. 2016; Yabiku et al. 2010).

It is against this backdrop of outmigration and feminisation of agriculture that we frame our study around men's and women's changing opportunity spaces in the drylands of eastern Kenya, and attempt to shed light on the dynamics of rural aspirations in relation to both gender and age. Using a novel methodology combining short narratives with semi-structured interviews and focus group discussions (FGDs), we contribute to a more nuanced understanding of aspirations and the wider socio-cultural context within which they are embedded and make several recommendations for progressing aspirations research.

\section{Methods}

Data consisted of 138 short aspirational narratives from 88 women and 50 men living in Makueni County, Kenya, and were supported by several additional co-located datasets from a land restoration project, including four FGDs on men's and women's 


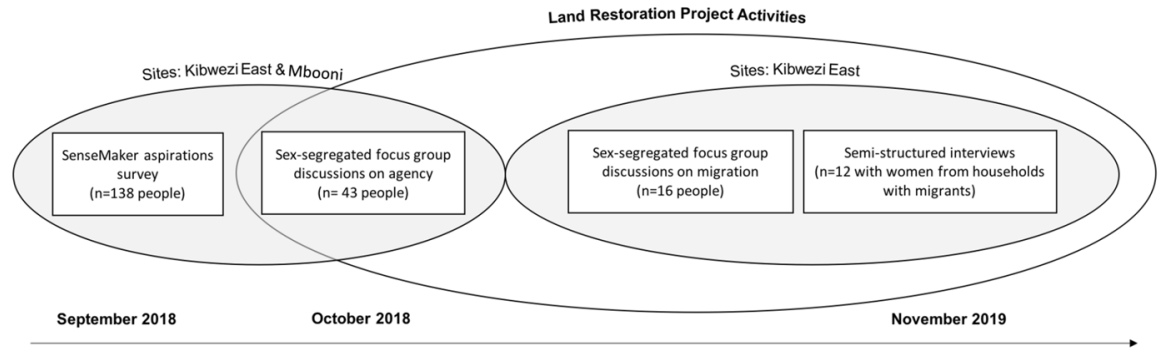

Fig. 1 Overview and chronology of methods

agency, two FGDs on local migration trends, and 12 semi-structured interviews with women from households with migrant members (Fig. 1).

\section{Study Area}

Makueni County, located in a semi-arid area of south eastern Kenya, is characterised by small-scale rainfed agriculture and experiences frequent drought and crop failures due to increasingly erratic and unreliable rainfall (KNBS 2019). Due to subdivision of land and population growth, farms are small with an average farm size of 1.2 hectares (GoMC 2018). Agricultural productivity is further limited by widespread land degradation in the form of soil erosion and low inherent soil fertility. Consequently, there are high levels of both poverty and food insecurity (KFSSG 2019). With marginal farming conditions and insufficient off-farm employment opportunities locally, many people, particularly men, are increasingly choosing to migrate in search of employment to nearby towns or larger urban areas such as Nairobi and Mombasa (GoMC 2019; Ifejika Speranza 2006).

Intrahousehold roles and relations in the area remain predominantly governed by patriarchal norms, with the husband seen as the head of the household and breadwinner and the wife as the carer of the home and children (Ifejika Speranza 2006). Despite Kenya's constitution granting men and women equal rights to inherit and own land, in practice, women's land rights remain restricted by customary practices whereby women rarely inherit land themselves and typically attain secondary use rights through their husband following marriage (Musangi 2017). Men therefore tend to have greater access to and control over land and, in turn, a greater social legitimacy with regards to decisions about agricultural activities and income (Dolan 2001).

\section{Aspirations Survey}

The first phase of data collection involved SenseMaker®, a narrative-based survey tool, whereby respondents tell a short story in response to an initial prompting question and then interpret their narrative using a set of predefined self-assessment questions (Cognitive Edge 2020; Mausch et al. 2018). While the SenseMaker ${ }^{\circledR}$ tool 
(1) Imagine your life in 10 years time, tell a story about how you got to that point from this present day?

In ten years time I want to educate my three children who are in high school up to university level and make sure that they secure good jobs. I also want to increase my livestock to a good number so that I can be able to sell them in times of need. I also want to be a big farmer of maize crops who can supply to the cereal shops in Makueni town. (Female, 35-45 years, head of household)

(2)

In the story shared, the main character of the story felt ...

Not confident that they can achieve their goals

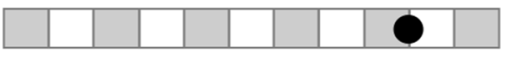

Confident they can achieve their goals

In the story shared, the world I live in ...

Has/had no opportunities

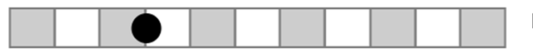

Is filled with opportunities

In the story shared...

People spent all of

their time farming

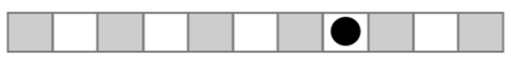

People spent all of their time on other things

In the story shared...

People don't care about improving their farming

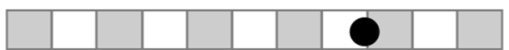

People will always try to improve their farming

If you farm, how do you spend your time when you're not farming?

I do casual jobs. I am a single mother of three who is trying to make ends meet.

Fig. 2 Example responses to opening question (1), self-assessment dyads (black dot) (2) and follow-up question (3) used in the SenseMaker® survey tool

has been used to explore complex social issues including people's understandings of climate change adaptation (Lynam and Fletcher 2015), it has not been used in the analysis of rural aspirations. This exploratory study is a first attempt to use it to capture aspirations and was conducted as part of a wider project exploring its application in operationalising livelihood aspirations for rural development (see Mausch et al. this issue).

To capture individual's envisioned futures, we asked respondents: "Imagine your life in 10 years' time, tell a story about how you got to that point from this present day?". This opening question was intended to evoke an unrestricted response and deliberately did not mention farming or non-farming activities. Respondents were then asked to interpret their stories or narratives using a set of predefined assessment questions. ${ }^{3}$ In this paper, we focus on the narratives themselves and a subset of self-assessment questions designed to explore men's and women's attitudes towards farming, the degree to which they feel they have opportunities in life, and their perceived confidence in achieving their aspirational goals (Fig. 2). This subset

\footnotetext{
${ }^{3}$ See Mausch et al. (this issue) for full description of the SenseMaker survey.
} 
of questions included the use of dyads, where respondents rate their narrative using a sliding-scale between two opposing statements (resulting in a score between 0 and 100), an open-answer question on how they spend their time when they are not farming, and several multiple-choice questions regarding demographic characteristics of the respondent (i.e. age, gender and position in household). The survey was conducted in September 2018 by a team of trained enumerators recruited from Makueni and administered using tablets. Each respondent was surveyed in private and their story translated and transcribed into English before being asked to interpret their story using the self-assessment questions.

Survey locations were co-located with the activities of a five-year land restoration project working with 645 farmers across two sites located in Makueni County: Kibwezi East and Mbooni constituencies (World Agroforestry 2020) (Table 1). This allowed us to draw on several additional qualitative datasets collected by the project within the same rural communities. For the aspirations survey participants, a sampling frame was utilised whereby ten villages were randomly selected and from each village, ten households were randomly selected from the village roster. In each household, the household head was surveyed followed by either their spouse or a child based on random selection. No replacements were made for unavailable respondents. This sampling procedure resulted in a total of 138 storytellers across a range of age groups and positions within the household (Table 1). The resulting sample, however, shows a bias towards women and older age groups since men and youth were often unavailable to take the survey (i.e. children were in school and men had migrated or were working off-farm during the time of interview).

\section{Focus Group Discussions and Semi-structured Interviews}

The second phase of data collection involved FGDs on agency, intrahousehold gender relations and local migration trends, and semi-structured interviews with women from households with migrant members. These field activities were co-located with the aspirations survey and provided additional information on the social context within which men's and women's aspirations were embedded.

The first set of FGDs were held in October 2018 in both Kibwezi East and Mbooni (a total of four groups, two with women only and two with men only). One of the aims of these discussions was to explore recent changes in women's agency understood as the "ability to define one's goals and act upon them" (Kabeer 1999, p. 438). We used an adapted version of the 'Ladder of Power and Freedom' ranking exercise described in Petesch et al. (2018). This involved asking participants to vote, in private, on which step of a five-step ladder best represented the majority men and women in their community in terms of their current level of agency and that of five years ago (i.e. 2013), and then discussing the reasons for men's and women's movement, if any, up or down the ladder. A five-year period was chosen instead of the ten-year period used by Petesch et al. (2018) so as to improve recall.

An additional round of FGDs was held in November 2019 in Kibwezi East (two groups, one with women only and one with men only) to explore gender-specific migration trends and drivers and recent changes in opportunities in agriculture. 
Table 1 Characteristics of farmers engaged in the land restoration project and SenseMaker® aspirations survey respondents

\begin{tabular}{|c|c|c|c|c|c|}
\hline \multicolumn{3}{|c|}{ Land restoration project } & \multicolumn{3}{|c|}{ SenseMaker aspirations survey } \\
\hline Men $(n=143)$ & $\begin{array}{l}\text { Women } \\
(\mathrm{n}=502)\end{array}$ & $\begin{array}{l}\text { All } \\
(n=645)\end{array}$ & $\begin{array}{l}\text { Men } \\
(n=50)\end{array}$ & Women $(\mathrm{n}=88)$ & $\begin{array}{l}\text { All } \\
(n=138)\end{array}$ \\
\hline
\end{tabular}

\begin{tabular}{|c|c|c|c|c|c|c|}
\hline \multicolumn{7}{|c|}{ Relation to household head ${ }^{\mathrm{a}}$} \\
\hline Household head & - & - & - & $47(94 \%)$ & $27(31 \%)$ & $74(54 \%)$ \\
\hline Spouse & - & - & - & $0(0 \%)$ & $59(67 \%)$ & $59(43 \%)$ \\
\hline Child & - & - & - & $3(6 \%)$ & $2(2 \%)$ & $5(4 \%)$ \\
\hline \multicolumn{7}{|l|}{ Marital status $^{\mathrm{b}}$} \\
\hline Married & $119(83 \%)$ & $417(84 \%)$ & $536(83 \%)$ & - & - & - \\
\hline Divorced & $2(2 \%)$ & $13(3 \%)$ & $15(2 \%)$ & - & - & - \\
\hline Widowed & $6(4 \%)$ & $47(9 \%)$ & $53(8 \%)$ & - & - & - \\
\hline Single & $16(11 \%)$ & $25(5 \%)$ & $41(7 \%)$ & - & - & - \\
\hline \multicolumn{7}{|l|}{ Age group $^{\mathrm{a}}$} \\
\hline Under 25 & $7(5 \%)$ & $18(4 \%)$ & $25(4 \%)$ & $3(6 \%)$ & $5(6 \%)$ & $8(6 \%)$ \\
\hline $25-34$ & $13(9 \%)$ & $103(21 \%)$ & $116(18 \%)$ & $7(14 \%)$ & $17(19 \%)$ & $24(17 \%)$ \\
\hline $35-44$ & $38(27 \%)$ & $145(29 \%)$ & $183(28 \%)$ & $9(18 \%)$ & $26(29.5 \%)$ & $35(25 \%)$ \\
\hline $45-54$ & $35(24 \%)$ & $144(29 \%)$ & $179(28 \%)$ & $9(18 \%)$ & $14(16 \%)$ & $23(17 \%)$ \\
\hline Over 54 & $50(35 \%)$ & $92(18 \%)$ & $142(22 \%)$ & $22(44 \%)$ & $26(29.5 \%)$ & $48(35 \%)$ \\
\hline \multicolumn{7}{|c|}{ Farm size (hectares) ${ }^{\mathrm{b}}$} \\
\hline Under 25 & $3.3(2.4)$ & $2.4(1.5)$ & $2.7(1.7)$ & $6.6(8.3)$ & $1.2(0.6)$ & $3.2(5.3)$ \\
\hline $25-34$ & $5.6(10.0)$ & $2.7(2.2)$ & $3.0(4.0)$ & $1.6(1.7)$ & $2.9(4.8)$ & $2.5(4.1)$ \\
\hline $35-44$ & $5.7(8.7)$ & $4.1(5.1)$ & $4.4(6.0)$ & $2.4(1.4)$ & $2.6(3.3)$ & $2.5(2.9)$ \\
\hline $45-54$ & $3.6(4.0)$ & $4.2(4.3)$ & $4.1(4.3)$ & $4.2(4.7)$ & $4.4(4.6)$ & $4.3(4.6)$ \\
\hline Over 54 & $7.1(8.4)$ & $6.4(10.9)$ & $6.6(10.1)$ & $8.5(9.4)$ & $5.6(7.7)$ & $6.9(8.5)$ \\
\hline All ages & $5.5(7.6)$ & $4.2(6.1)$ & $4.5(6.5)$ & $4.4(7.3)$ & $3.8(5.4)$ & $4.4(6.2)$ \\
\hline \multicolumn{7}{|l|}{ Household size $e^{\mathrm{b}}$} \\
\hline Under 25 & $6.1(1.2)$ & $4.4(1.7)$ & $4.9(1.7)$ & $8.7(2.1)$ & $4.4(2.3)$ & $6.0(3.0)$ \\
\hline $25-34$ & $4.6(2.0)$ & $5.1(3.3)$ & $5.1(3.2)$ & $3.9(0.4)$ & $3.9(0.6)$ & $3.9(0.5)$ \\
\hline $35-44$ & $5.6(1.5)$ & $5.6(1.5)$ & $5.6(1.5)$ & $4.8(2.0)$ & $4.9(1.4)$ & $4.9(1.6)$ \\
\hline $45-54$ & $6.4(1.9)$ & $6.5(2.2)$ & $6.5(2.2)$ & $4.7(2.3)$ & $3.5(2.1)$ & $4.0(2.2)$ \\
\hline Over 54 & $6.1(3.1)$ & $6.4(2.8)$ & $6.3(2.9)$ & $4.3(2.9)$ & $4.0(2.2)$ & $4.1(2.5)$ \\
\hline All ages & $4.4(1.5)$ & $5.8(0.9)$ & $5.9(2.5)$ & $4.7(2.5)$ & $4.2(1.8)$ & $4.4(2.1)$ \\
\hline
\end{tabular}

${ }^{\text {a }}$ Statistics presented: $\mathrm{n}(\%)$

${ }^{\mathrm{b}}$ Statistics presented: mean (SD)

Twelve semi-structured individual interviews were also conducted with women from households with migrant members. These interviews covered similar topics to the FGDs but focused on women's personal experiences and those of migrant household members.

For both sets of FGDs, stratified random sampling was used to select male and female participants from a list of farmers registered with the land restoration 
Table 2 Participant characteristics for migration focus group discussions (FGDs) and semi-structured interviews

\begin{tabular}{llll}
\hline & \multicolumn{2}{l}{ Migration FGDs } & Migration interviews \\
\cline { 2 - 3 } & Men $(\mathrm{n}=8)^{\mathrm{c}}$ & Women $(\mathrm{n}=8)$ & Women (n=12) \\
\hline Age $^{\mathrm{a}}$ & $38.8(4.7)$ & $43.4(11.3)$ & $46.6(6.1)$ \\
Farm size (hectares) $^{\mathrm{a}}$ & $10.9(16.4)$ & $10.4(13.3)$ & $2.9(3.1)$ \\
Household size $^{\mathrm{a}}$ & $4.4(1.5)$ & $5.75(0.9)$ & $5.8(1.4)$ \\
Marital status $^{\mathrm{b}}$ & & & \\
Married & $4(80 \%)$ & $7(88 \%)$ & $10(83 \%)$ \\
Divorced/widowed & $1(20 \%)$ & $1(12 \%)$ & $2(16 \%)$ \\
Migrant(s) relation to household head & & & \\
Themselves/household head & $2(17 \%)$ & $0(0 \%)$ & $0(0 \%)$ \\
Spouse & $0(0 \%)$ & $4(50 \%)$ & $9(75 \%)^{\mathrm{d}}$ \\
Son & $0(0 \%)$ & $1(12 \%)$ & $11(92 \%)$ \\
Daughter & $1(13 \%)$ & $1(12 \%)$ & $5(42 \%)$ \\
No migrants & $6(75 \%)$ & $3(37 \%)$ & - \\
\hline
\end{tabular}

${ }^{\text {a }}$ Statistics presented: $\mathrm{n}(\%)$

${ }^{\mathrm{b}}$ Statistics presented: mean (SD)

${ }^{\mathrm{c}}$ Missing data for three male participants

${ }^{\mathrm{d}}$ Two husbands were retired migrant workers and four worked locally, returning home each evening

project and to ensure representation of men and women involved in different project interventions. For the migration FGDs, stratified random sampling was employed to enrol men and women from households with and without migrant members (Table 2). Group sizes ranged from 5-22 participants with a total of 14 men and 29 women in 2018, and 8 men and 8 women in 2019. For the semi-structured interviews, 12 women were purposively selected from project households to represent a range of different household situations, including women with migrant sons, husbands and daughters (Table 2). Age was not a selection criterion for the FGDs or interviews as the majority of farmers participating in the project are within a certain age range (50\% of participants are aged 35-53). Although age was not an explicit consideration in our selection criteria, participant ages ranged from 34 to 70 years in the FGDs and 37-56 years in the interviews (Table 2).

\section{Data Analysis}

Qualitative analysis was conducted using NVivo 11 software (QSR International 2015). Narratives from the aspirations survey were first deductively coded for content analysis based on whether they mentioned farming or non-farming-related aspirations or both. Additional codes were then developed inductively based on thematic analysis and cross-case comparisons conducted with respect to gender and age. Dyad self-assessment questions were analysed in the $R$ software environment $(R$ Core Team 2020) and the Wilcoxon rank-sum test used to compare responses from 
respondents. Textual data from the FGDs and interviews were inductively coded based on responses and dominant topics raised by participants.

\section{Results}

\section{Migration Trends and Drivers}

During our FGDs on migration, both men and women reported that migrants from their community tended to be younger adult men, leaving to find casual jobs in cities, such as Nairobi or Mombasa, or to work as labourers on large farms. These migrants generally returned home weekly or monthly to visit their families but usually for only a few days at a time.

The main reason given by interviewees for the migration of household members was to earn additional income and support their families. Migration was seen as part of a household strategy, with an individual's decision to migrate often having been discussed and decided on as a household. Several women, for example, reported involvement in their son's decision to migrate, allowing them to leave so that they could support the family financially. Some had even funded their children's migration using their savings or through selling livestock.

It was also mentioned that young men may leave if their parents' farm is small and they do not have land to farm. However, several women indicated that young people lacked an interest in farming. One explained that, while her migrant son aspires to farm and continues to keep cattle, young people, in general, do not like farming since it is "not a prestigious and professional job". Another reported that her migrant son had previously been involved in farming "but became lazy due to the [poor] rain". One woman also stated that her son had applied for a job immediately after finishing school since "anyone who has finished school is supposed to get a job".

During the FGDs, men reported that while many of the male migrants in their community were still young, they expected that most would return to the community in their retirement. Although none of the women interviewees reported that they or their families planned to join their migrant members, six anticipated that their migrant sons would one day move back to their village permanently, and two expected their husbands would return permanently once they retire. Both groups reported that the number of adult men leaving had increased over the past five years due to deteriorating climatic conditions and increasingly poor rainfall.

Although still a minority, participants reported that the number of unmarried women leaving in search of work had also increased. However, both groups agreed that women, and in particular those who are married, have fewer opportunities to migrate and are expected to stay and look after the home and children. Several men joked that there is a fear that a married woman will "get into bed with a man who drives a black car", implying she may find another husband with a more stable income. They also argued that it is risky for women to migrate since they may find themselves homeless while searching for work; a situation that men are more 


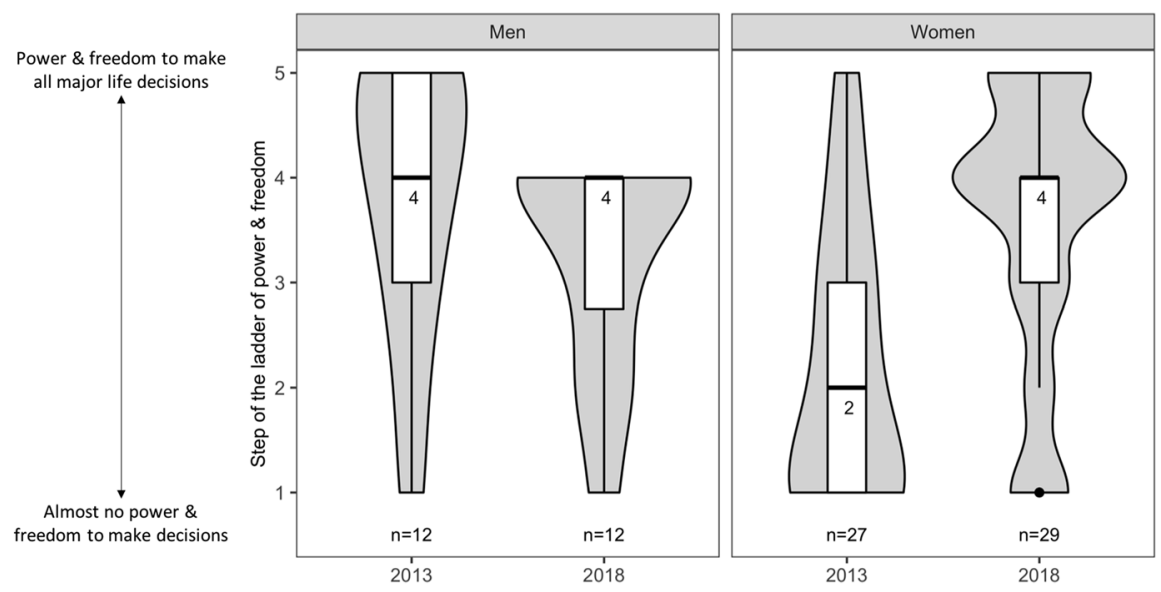

Fig. 3 Men's and women's votes from the Ladder of Power and Freedom exercise with median scores shown

capable of navigating given that they can sleep "in a ditch beside the road", while a woman cannot.

\section{Men's and Women's Agency and Opportunities in Agriculture}

During the Ladder of Power and Freedom exercise, women participants indicated a substantial increase in agency over the past five years (Fig. 3). Reasons for these changes included increased awareness of women's rights through constitutional changes and seminars, the outmigration of men, and women's increased participation in agricultural training. While women were said not to have been valued five years ago with men having made all major decisions, farming and household decisions now tend to be discussed and made together as a household. Women reported that agricultural training events now include both men and women and that through these engagements, men had seen that women are capable of contributing ideas and carrying out tasks typically assigned to men, such as terracing and fencing. Women also stated that it is now common for men to work outside the homestead and so women have more freedom to make decisions independently. One woman gave the example that her migrant husband was unaware she was attending the FGD and that she was the one who has to decide what is best for the family while he is away. Nevertheless, several women emphasised that a woman must still respect her husband since he is the household head and the one who has given her the freedom to make decisions independently.

Women also explained that age and position in the household are important factors in the level of agency they possess. For example, women on step five of the ladder (i.e. power and freedom) were said to be "mature people who can make decisions on their own" or widows, while those on step one (i.e. no power or freedom) were likely elderly women living with, and depending on, their children. One woman explained from her own experience that her decision-making authority had 
increased when she got married and had children since she now has to make decisions for her children and tells them where to work and what to do on the farm.

In contrast to women, male participants indicated a small decrease in men's power and freedom in recent years. Their reasons mirrored those raised by women. In the past, men had been in charge of all household decisions without question but that, as women and children had become more educated, men now acknowledge they have valuable knowledge and ideas on how to improve and develop the family and will consult their wives and family members. Nevertheless, men still regarded themselves as having more decision-making authority than their wives.

Asked whether the opportunities in agriculture for men and women had changed over the past five years, two reoccurring themes emerged from the FGDs and interviews. On the one hand, opportunities had proliferated due to increased agricultural training and better knowledge of new farming practices such as the application of pesticides, use of soil and water conservation techniques and poultry keeping. On the other, farming conditions were said to have worsened due to poor and unreliable rainfall. As one women interviewee explained, "There is an improvement. We have been trained in better methods of farming and have good varieties of seed favourable to this area, but the rains fail us".

There was a consensus that women had benefited the most from increased opportunities in agriculture, since they are the ones mainly involved in farming and who attend training events, while men look for off-farm income. Women interviewees saw farming as a way to earn income and provide food for their families, and their plans for the future included gaining access to water for commercial production of vegetables, poultry farming and starting small shops to sell their produce. Nevertheless, several interviewees indicated that women's involvement and interest in farming is born out of necessity rather than choice. As one woman explained, mainly women are interested in farming, "because men move and leave the women and children behind. These women have no option but to work on their farms". Another stated, "[women] are the ones burdened with raising their children compared to their husbands. The women provide the food, clothes and are more concerned compared to the men. The men leave early and come back late they don't even know when the children are hungry". Such accounts imply that, while women's opportunities in agriculture are thought to be increasing, norms designating them as carers of the household and as vulnerable in urban settings, constrain their ability to explore opportunities outside of farming.

\section{Aspirations Survey: Men's and Women's Envisioned Futures}

Although we did not ask aspiration survey respondents (storytellers) directly whether their spouses had migrated, $23 \%$ of women mentioned that their husbands were temporarily absent or lived and worked away. A further 5\% were divorcees and $10 \%$ were widows, likely explaining the high percentage of women storytellers self-identifying as the household head (27\%). Most men and women perceived their stories as positive (98\%); however, women saw their world filled with fewer opportunities than men had and, although still high (median of 74\%), 
Table 3 Summary statistics for self-assessment dyads

\begin{tabular}{|c|c|c|c|c|c|c|}
\hline & $\mathrm{N}$ & Mean & Median & Std. Dev & Min & Max \\
\hline \multicolumn{7}{|c|}{ Level of confidence in achieving goals $(0-100)$} \\
\hline Men & 49 & $79.82^{*}$ & 81.00 & 11.68 & 52.00 & 95.00 \\
\hline Women & 85 & $73.46^{*}$ & 74.00 & 14.09 & 33.00 & 97.00 \\
\hline \multicolumn{7}{|c|}{$\begin{array}{l}\text { Level of perceived opportunities in life } \\
\quad(0-100)\end{array}$} \\
\hline Men & 50 & $57.70^{*}$ & 65.00 & 21.54 & 16.00 & 88.00 \\
\hline Women & 86 & $49.37 *$ & 59.00 & 22.24 & 5.00 & 87.00 \\
\hline \multicolumn{7}{|c|}{$\begin{array}{l}\text { Share of time spent } \\
\text { farming }(0-100)\end{array}$} \\
\hline Men & 48 & $54.33^{*}$ & 67.00 & 29.29 & 4.00 & 92.00 \\
\hline Women & 83 & $65.72 *$ & 75.00 & 23.81 & 0.00 & 92.00 \\
\hline \multicolumn{7}{|c|}{$\begin{array}{l}\text { Degree to which people care about } \\
\text { improving their farming }\left(0_{-100)}\right.\end{array}$} \\
\hline Men & 45 & 73.84 & 75.00 & 14.23 & 19.00 & 95.00 \\
\hline Women & 81 & 71.64 & 74.00 & 13.44 & 13.00 & 89.00 \\
\hline
\end{tabular}
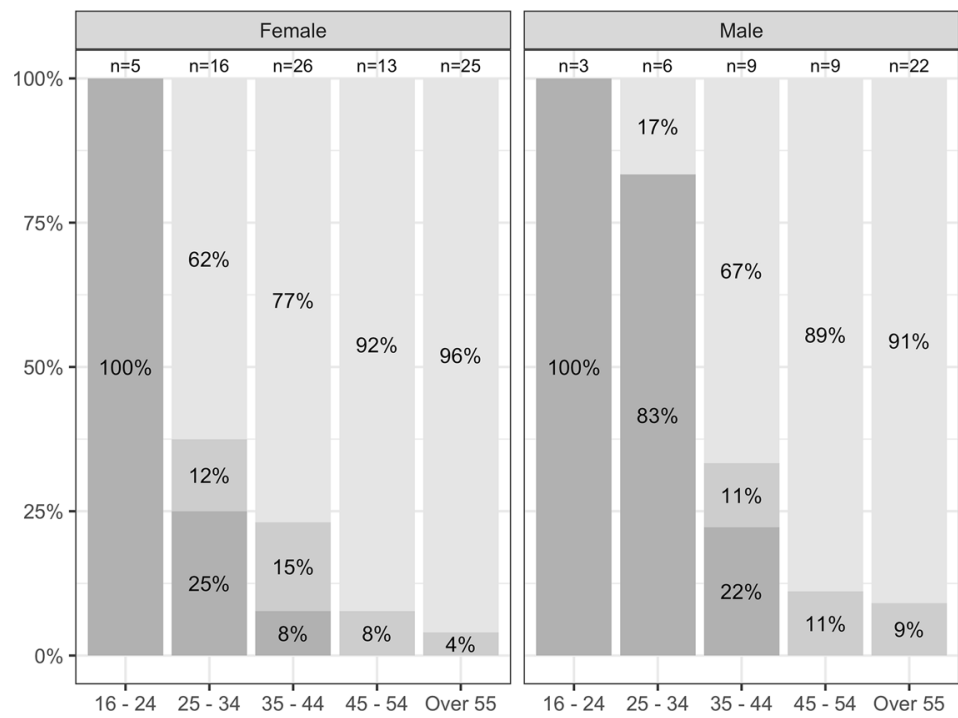

Farming

Both

Non-farming

Fig. 4 Aspirations of men and women storytellers across age groups, categorised by whether they mentioned non-farming or farming-related aspirations in their stories or both

were less confident in achieving their goals (Table 3). Women also envisioned spending more of their time farming than men, yet both men and women indicated to a similar degree that they care about improving their farming, perhaps reflecting men's intentions to return to farming when they retire. 
There were distinct trends in aspirational focus with age and gender (Fig. 4). None of the men or women under 25 aspired to farm. Instead, their aspirations focused on their education, securing employment, starting their own businesses and rescuing their families from poverty. Men's and women's aspirations then diverged and re-converged with age. While most women aged 25-35 aspired to invest in agriculture, men of the same age aspired to own businesses, find employment and saw farming as a largely secondary activity. Conversely, despite many women in this age group reporting that in addition to farming they currently look for casual work or have small businesses, they spoke of becoming "established" and "large-scale" farmers, with farming seen as a way of earning income. As one woman explained, "I have 40 mango trees now which I want by 2028 to increase to 200 trees so I may be able to sell many bags of fruits and be able to give me income. I also plant crops like maize, vegetables and beans. I also have ten goats which I want to increase and sell to gain profits".

There was an increased focus on agricultural activities for men and women aged 35-44 years. Nevertheless, it was again women rather than men who emphasised commercialising their agricultural activities. One woman even aspired to own a tractor and to become a "full-time farmer", despite later indicating that she currently runs a small boutique in her local market: "I want to keep a lot of poultry and ensure I am a full-time farmer. I want to also take part in large-scale crop farming using tractors by planning to buy my own tractor". Such findings challenge the notion that rural women are primarily interested in farming for home consumption.

Among older cohorts, both men's and women's aspirations coalesced towards agriculture with men over 45 years often looking to retire from their off-farm occupations and return to farming. As one man aged 45-54 explained, "in the next ten years I want to buy tanks and store rain water and start irrigation. I have already bought two that hold 10,000 L and will add more soon. Currently I am a casual worker in Nairobi about to retire". Furthermore, unlike younger cohorts, it was primarily men within the over 55 age group who emphasised commercial production and wanting to sell their farm produce to "big markets", perhaps reflecting their return to farming following retirement. As one man illustrated, "since I am a retired teacher I want to be a farmer. I would like to plant mango trees and keep poultry. I want to take farming more seriously than before because right now I have the time".

While storytellers' farming aspirations were diverse, the specific activities mentioned by men and women did not significantly differ. Common activities mentioned by both men and women included digging farm ponds or buying water tanks, acquiring more livestock or land, starting dairy farming or poultry farming and growing horticultural crops. There was also a strong focus on planting fruit trees, especially mango. Unlike younger cohorts, men and women over 55 planned to move into less labour-intensive activities such as poultry and fruit trees given that crop farming would likely become difficult due to old age. In contrast to farming activities, non-farming occupations and aspirations held by men and women were often stereotypically associated with their gender. For example, women's non-agricultural aspirations often included owning a hair salon or clothing business, or starting a kiosk or grocery store in the local market, while men spoke of owning their own 
transportation businesses, working in construction, becoming a mechanic or building rental apartments.

Storytellers also mentioned non-occupational aspirations. For example, two of the women under 25 wished to rescue their families from poverty, while one young man who aspired to be a politician stated that he wanted to "improve the lives of his people". In older cohorts, non-occupational aspirations focused heavily on educating children, specifically to tertiary level, so that they could "secure good jobs", "get employed" and earn an income. $43 \%$ of men and women over 25 mentioned wanting to educate their children and investing in farming was often seen as a way of earning money in order to do so, especially by women. Several men and women over 55 planned to depend on their children in their old age. As one woman explained, "I have no plans. I will just continue with small-scale farming as I have always done. My children are grown up, so when they stabilise I expect them to take care of me".

\section{Discussion}

Four key points emerge from our exploratory study. First, women are likely to be important catalysts of agricultural innovation and investment amid the increasing outmigration of men and feminisation of farm management. Secondly, if rural aspirations are to be used to target development efforts more effectively, researchers will need to consider the aspirations of multiple household members and how they interrelate and are mediated at the household level. Third, attention should be paid to gendered and intergenerational roles and relations within the household and, fourthly, to how men's and women's opportunity spaces change throughout life. In the following section, we discuss these four points and their implications for future aspirations research.

\section{Women's Increasing Agency and Opportunities in Agriculture}

A common narrative within agricultural development is that women, given their responsibility for feeding the family, are primarily interested in innovations related to food production for home consumption, whereas men are more concerned with those aimed at optimising agricultural income (Doss 2001; Fisher and Carr 2015; Shibata et al. 2020). While this narrative is not unfounded, we contend that, at least in the context of eastern Kenya and increasing male outmigration, such notions may require re-examining.

We found that, while middle-aged men often aspired to invest in off-farm income sources, women largely aspired to invest in and commercialise their agricultural activities and saw farming as an opportunity, not only to provide food for their families, but to earn an income. Even women who reported having offfarm income sources often aspired to expand their current farming activities to increase earnings. These findings are in contrast to those of Rietveld et al. (2020) and Elias et al. (2018) who found that, in several sub-Saharan contexts, women's agricultural aspirations are constrained by social norms designating farming 
and, in particular, commercial agriculture, as an occupation better suited to men. Unlike the majority of women in our study, none of the young Ugandan women interviewed by Rietveld et al. (2020) aspired to be farmers, and when farming was considered as part of their future livelihood, their interest was generally limited to farming for subsistence or as a means of diversification. This is not to say that in our study women's interest in farming is not initially shaped by norms and attitudes that constrain their off-farm opportunity space and limit their options to primarily farming-related activities (Van den Broeck and Kilic 2019). For example, similarly to Ifejika Speranza (2006), we found evidence for norms and attitudes discouraging married women from engaging in migratory employment.

Furthermore, although off-farm income activities mentioned by storytellers were often stereotypically associated with their gender, the differences in the farming-related aspirations mentioned by men and women were limited. However, it is worth noting that the opening question to our aspirations survey was purposefully neutral and without reference to farming or non-farming activities so as to elicit an unrestricted response across all possible livelihood strategies. Consequently, storytellers often referred to "farming", rather than specifying the specific types of agricultural activities they wished to pursue. Further questioning around the types of farming people aspired to invest in may therefore have revealed greater variation between men's and women's aspirations within agricultural strategies.

The feminised focus on agricultural investment revealed by our study likely reflects women's changing agricultural opportunity space amid the increasing offfarm employment and outmigration of men. While the temporary migration of adult men has long been a recurring trend within our study area (Tiffen et al. 1995), the numbers of those leaving for cities in search of work was reported to have increased in recent years, and almost a quarter of women storytellers reported that their husbands live and work away. As a result, women are the ones largely attending agricultural training events, gaining knowledge of new technologies and taking advantage of new opportunities in agriculture. Furthermore, women's participation in, and agency over, household and farming decisions is thought to have increased substantially in recent years due, at least in part, to the absence of their male household members. These findings are similar to other studies, including those conducted in Kenya, indicating that women's increased agricultural training can increase their confidence and involvement in farming decisions (Bullock and Tegbaru 2019; Nyasimi and Huyer 2017), and that women with absent husbands may gain greater personal autonomy and power over household decisions (Yabiku et al. 2010).

Rietveld et al. (2020) suggest women's disinterest in commercial farming stems from the likelihood that their husbands will claim any resulting revenue. Likewise, in Meru County, Kenya, Dolan (2001) document that rural women are often reluctant to take on certain commercial crops since it increases their workload, but not their controlled income. Hence, the accounts of women in this study which frame farming as a potential income-generating opportunity may be indicative of a dynamic whereby, with men away from home (i.e. engaged in migratory work), women gain more control over the financial rewards of farming and, as a result, are increasingly interested in pursuing commercial agricultural activities. 
Several pertinent questions and lines of enquiry emerge from the above findings. One such question is whether women's increased agency reflects lasting changes in family relations and gender-related norms, or whether these gains are simply a practicality in the physical absence of men. Encouragingly, Yabiku et al. (2010) found that in southern Mozambique, increases in women's autonomy persisted even after their male relatives returned. In our study, however, male storytellers spoke of returning to farming once they retire, raising questions regarding women's security in their role as farm managers. As illustrated by Dolan (2001) with the commercialisation of French bean production in Meru, men may also choose to appropriate women's agricultural enterprises once they are commercialised.

Another important question is whether people's aspirations are, in fact, attainable. While phrases such as 'I want to be a large-scale farmer' indicate that women are certainly interested in farming, their stories alone do not provide detail as to the scale of this envisioned production nor if these goals are realisable. Given small farm sizes and marginal farming conditions, the financial returns to women's investments in farming may well be limited. In light of this, we propose that combining narrative-based approaches, such as SenseMaker ${ }^{\circledR}$, with more conventional socioeconomic household surveys could prove more effective in informing the design of development efforts and identifying the barriers people face in attaining their aspired futures.

\section{Recognising Intrahousehold Heterogeneity of Aspirations}

Both Verkaart et al. (2018) and Mausch et al. (2018) argue that development projects could benefit from considering interhousehold variation in aspirations and targeting households who truly aspire to farm. Based on our findings, we further propose that rural development projects should identify those within the household who aspire to farm. Our study suggests that, at least in the drylands of eastern Kenya, it is often the women within rural households who are likely to be a key target group, given their interest and enthusiasm for farming and their increasing agency over management decisions. These conclusions, however, reveal an apparent shortcoming of current rural aspirations research - a lack of consideration of the intrahousehold heterogeneity of aspirations and that asking for the aspirations of only one household member is likely to provide a biased picture of a household's desired livelihood trajectory.

Research on rural livelihood strategies tends to focus on the household as the unit of analysis and usually relies on surveys conducted with one household member, often the household head. However, in contexts where adult men frequently engage in off-farm income-generating activities, studies that ask only for the aspirations of the household head risk concluding that rural households do not aspire to grow the agricultural aspects of their income portfolios but instead wish to focus on off-farm sources of income. If researchers are to utilise aspirations to target rural households more efficiently, it will be critical to assess the aspirations of multiple household members and how these interrelate and are mediated at the household level. 
For instance, in their assessment of aspirations among rural Kenyan households, Verkaart et al. (2018) evaluated livelihood strategies at the household level but subsequently only asked the survey respondent (presumably, often a male household head) what income-generating activities they personally aspired to invest in. Based on their analysis, they conclude that a sizable proportion of households aspire to invest in their non-farm income sources rather than in farming. From their sample of 624 households, $64 \%$ of respondents wanted to invest in farming, $41 \%$ in nonfarming activities and $9 \%$ in both farming and non-farming activities. Our research suggests, they may well have concluded otherwise had they considered the aspirations of multiple household members and, in particular, their wives. We therefore propose that researchers studying rural aspirations and livelihood dynamics could benefit from taking an approach that recognises that within a household, there may be those who wish to remain and engage in farming even when other members look to step out.

\section{Changing Opportunities, Interests and Capacities Throughout Life}

In line with Sumberg et al. (2012), our findings suggest that specific events throughout life, such as finishing school; inheriting land; getting married; and having children, work to reshape men's and women's opportunity spaces in distinct ways, opening up or constraining their interest and capacity to engage in farming or other activities. Specifically, our study, similar to Rietveld et al. (2020), highlights the interrelated role that marriage and access to land play in shaping men's and women's opportunities.

For both male and female storytellers, we found an increased focus on farming among older age groups. Supported by a general trend towards larger farm size with age (Table 1), this likely reflects young men's and women's limited access to and control over land, and thus their current lack of opportunities in farming. In our study area, young men tend to inherit land once they are married or must wait until they have saved up sufficient capital to purchase land of their own, while women generally gain access to land through their husbands following (Musangi 2017). Moreover, young men's and women's access to land is likely to be further constrained by the successive subdivision of land through inheritance (Jayne et al. 2014).

For men, an increased focus on farming with age is also likely to reflect a return to farming in their retirement. For women, marital status seems to play an additional role in shaping their engagement in farming. In Kenya, getting married marks a person's transition into adulthood and, for many women, a point at which certain options in life, such as education and formal employment, foreclose (Ikamari 2005). For instance, norms discouraging women's engagement in migratory labour appear to be less binding for younger, unmarried women in Makueni County. Once married, however, women are expected to remain on-farm and take care of the home and children.

While the above findings provide initial insights into the dynamic nature of aspirations, it is important to note that our collected narratives provide only a snapshot 
of people's aspirations and are likely biased towards those who remain living in rural areas, as indicated by the low numbers of youth and men in our sample. It is therefore unclear to what extent young men and women who aspire to move out of farming do so and are therefore not captured in our sample, and whether the trend in men's and women's stories towards farming-related aspirations with age reflects a socio-cultural shift in aspirations away from farming. Answering such questions, however, will require further in-depth enquiry, for instance using longitudinal studies that track people's aspirations over time and how aspirations play out throughout life and with men's and women's changing circumstances and social identities.

\section{Understanding Intrahousehold Roles and Relations}

Our research also highlights the need to consider how individual livelihood strategies and aspirations interrelate and are mediated at the household level. While individuals within the same household may differ in their preferences and priorities, household members often own and manage resources collectively and make decisions together to achieve mutually beneficial outcomes (Doss and Meinzen-Dick 2015; Doss and Quisumbing 2020). In our study, men's and women's diverging and converging aspirations with age likely reflect gender- and age-dependent divisions of labour and familial responsibilities, and even a negotiated household strategy. For example, there is a sense that children are expected to focus on their education so that they can secure employment and provide their families with long-term financial security. For married women, responsibilities shift towards caring for the household, raising children and managing the farm, while men continue to engage in off-farm income activities, either locally or further afield, until their retirement. Furthermore, migration was seen as part of a household strategy, with a migrant's decision to leave often reported to have been discussed and decided on as a household.

Given women's stated agency and increased involvement in household decisions in recent years, one could speculate that these gender-differentiated roles and responsibilities reflect a negotiated, and even preferred, position for women. As argued by Archambault (2010), while the term 'left-behind' designates rural women as passive actors in their husband's migration and residency decisions, rural women may also choose to remain out of their own volition. In their study on rural women's autonomy amid male outmigration in north-eastern Tanzania, Archambault (2010) found that women may chose to remain given increased autonomy over their labour and work schedule. Similarly, in central Kenya, Nelson (1992), report that women may remain for a variety of reasons, including increased personal and economic autonomy in the absence of their husbands, a feeling of being appreciated by their families and seeing farming as their way of contributing to their household's welfare, as well as an aversion to urban life and the prospect of moving to the city, only to become a housewife.

Nevertheless, several women interviewees in our study framed their role in farming in a more negative light, even stating that 'women have no option but to work on their farms', and although women have experienced increased agency in recent years, it is evident that asymmetries in decision-making authority persist, with men 
still seen as the household head and final decision-maker. It is also worth noting that the women participating in our FGDs and interviews are those engaged in a land restoration project and unlikely to represent the heterogeneity of women within the community. For instance, the majority of women involved in the project are aged between 35 and 54, married and have access to land. Compared to younger women, especially those with young children, these women are likely better able to negotiate greater access to land, influence household decisions and have the time and mobility to attend project training events (Rietveld 2017). Although our Ladder of Power exercise focused on changes at the community level, its results likely hide considerable variation in the socially differentiated experiences of women and care should be taken not to overstate women's increased capacity to exercise agency. An important avenue for future aspirations research is therefore to explore to what extent aspirations are negotiated among household members and what this means in terms of different groups of women's actualized power to decide their own futures and that of their households.

\section{Conclusions}

In this study, we contribute to growing evidence that multiple social dimensions, including gender, age and household position, intersect to shape an individual's opportunity space and aspirations for the future. In the absence of men and presence of norms restricting women's movement out of rural life, women in Makueni are becoming increasingly engaged in farming both in terms of labour and management decisions. At the same time, women's participation in agricultural training has led to increased recognition of their capabilities as farmers and in their own confidence in managing the family farming enterprise. Challenging the notion that women are primarily interested in subsistence farming, women's aspirational narratives focused on intensifying and commercialising their farm activities, likely reflecting this changing opportunity space in agriculture and their new realities as farm managers.

Our findings also highlight that considering aspirations at only the household level ignores how individuals often contribute to and control different aspects of a household's livelihood portfolio and may aspire to invest their time and resources in distinct ways. Further, our study underscores how analysing aspirations at only the individual level overlooks the relations between household members and that aspirations are likely shaped by the views and actions of others. If development efforts are to utilise rural aspirations to target agricultural innovations more effectively, future research must move beyond studying the desired futures of individuals in isolation from their wider household, and move towards a more collective model that recognises the intrahousehold heterogeneity of aspirations and the dynamic nature of the gender and age-related roles and relations that underpin them.

Acknowledgments This work was undertaken as part of, and funded by the CGIAR Research Program on Grain Legumes and Dryland Cereals (GLDC), CGIAR Research Program on Policy, Markets and Institutions (PIM), CGIAR Research Program on Forest Trees and Agroforestry (FTA) and International Fund for Agricultural Development (IFAD), grant numbers 2000000520 and 2000000976 , project titled, 
"Restoration of degraded land for food security and poverty reduction in East Africa and the Sahel: taking successes in land restoration to scale". We would like to thank the women and men who participated in this research for sharing their time and insights, and gratefully acknowledge the support of the data collection team and community facilitators, including Stephen Maithya, Sylvester Muendo, Francisca Mutua, Mercy Mwea and Esther Kiura. We would also like to thank two anonymous reviewers for their valuable comments on earlier drafts of the manuscript.

\section{Compliance with Ethical Standards}

Conflict of interest The authors declare that they have no conflict of interest.

Open Access This article is licensed under a Creative Commons Attribution 4.0 International License, which permits use, sharing, adaptation, distribution and reproduction in any medium or format, as long as you give appropriate credit to the original author(s) and the source, provide a link to the Creative Commons licence, and indicate if changes were made. The images or other third party material in this article are included in the article's Creative Commons licence, unless indicated otherwise in a credit line to the material. If material is not included in the article's Creative Commons licence and your intended use is not permitted by statutory regulation or exceeds the permitted use, you will need to obtain permission directly from the copyright holder. To view a copy of this licence, visit http://creativecommons.org/licen ses/by/4.0/.

\section{References}

Appadurai, A. 2004. The Capacity to Aspire: Culture and the Terms of Recognition. In Culture and Public Action, ed. V. Rao and M. Walton. Palo Alto: Stanford University Press.

Archambault, C.S. 2010. Women left behind? Migration, spousal separation, and the autonomy of rural women in Ugweno. Tanzania. Signs 35 (4): 919-942.

Arslan, A., N. Mccarthy, and L. Lipper. 2013. Adoption and Intensity of Adoption of Conservation Farming Practices in Zambia. ESA Working Paper No. 13-01. Rome: Development Economics Division, Food and Agricultural Organisation.

Barrett, C.B., T. Reardon, and P. Webb. 2001. Nonfarm income diversification and household livelihood strategies in rural Africa: Concepts, dynamics, and policy implications. Food Policy 26: 315-331.

Bullock, R., and A. Tegbaru. 2019. Women's agency in changing contexts: A case study of innovation processes in Western Kenya. Geoforum 105: 78-88.

Chant, S., and S.A. Radcliffe. 1992. Migration and development: The importance of gender. In Gender and Migration in Developing Countries, ed. S. Chant. London: Belhaven Press.

Chirwa, E.W. 2005. Adoption of fertiliser and hybrid seeds by smallholder maize farmers in southern Malawi. Development Southern Africa 22 (1): 1-12.

Cognitive Edge. 2020. What is SenseMaker? Available at: https://sensemaker.cognitive-edge.com/whatis-sensemaker/. Accessed 22 Aug 2020.

Dolan, C. 2001. The 'Good Wife': Struggles over resources in the Kenyan Horticultural Sector. The Journal of Development Studies 37 (3): 37-41.

Dorward, A., S. Anderson, Y.N. Bernal, E.S. Vera, J. Rushton, J. Pattison, and R. Paz. 2009. Hanging in, stepping up and stepping out: Livelihood aspirations and strategies of the poor. Development in Practice 19 (2): 240-247.

Doss, C.R. 2001. Designing agricultural technology for African women farmers: Lessons from 25 years of experience. World Development 29 (12): 2075-2092.

Doss, C.R., and R. Meinzen-Dick. 2015. Collective action within the household: Insights from Natural Resource Management. World Development 74: 171-183.

Doss, C.R., and A.R. Quisumbing. 2020. Understanding rural household behavior: Beyond Boserup and Becker. Agricultural Economics 51 (1): 47-58.

Elias, M., N. Mudege, D.E. Lopez, D. Najjar, V. Kandiwa, J. Luis, J. Yila, A. Tegbaru, G. Ibrahim, L. Badstue, and E. Njuguna-mungai. 2018. Gendered aspirations and occupations among rural youth, 
in agriculture and beyond: A cross-regional prescriptive. Journal of Gender, Agriculture and Food Security 3 (1): 82-107.

Feder, G., R.E. Just, and D. Zilberman. 1985. Adoption of agricultural innovations in developing countries: A survey. Economic Development and Cultural Change 33 (2): 255-298.

Fisher, M., and E.R. Carr. 2015. The influence of gendered roles and responsibilities on the adoption of technologies that mitigate drought risk : The case of drought-tolerant maize seed in eastern Uganda. Global Environmental Change 35: 82-92.

Gassner, A., D. Harris, K. Mausch, A. Terheggen, C. Lopes, R. Finlayson, and P. Dobie. 2019. Poverty eradication and food security through agriculture in Africa: Rethinking objectives and entry points. Outlook on Agriculture 48 (4): 309-315.

Giller, K.E., E.C. Rowe, N. De Ridder, and H. Van Keulen. 2006. Resource use dynamics and interactions in the tropics: Scaling up in space and time. Agricultural Systems 88 (1): 8-27.

Glover, D., J. Sumberg, G. Ton, J. Andersson, and L. Badstue. 2019. Rethinking technological change in smallholder agriculture. Outlook on Agriculture 48 (3): 169-180.

Government of Makueni County. 2018. Makueni County Integrated Development Plan (CIDP) $2018-22$. Wote: Government of Makueni County.

Government of Makueni County. 2019. Makueni County Spatial Plan. Wote: Government of Makueni County.

Harris, D., and A. Orr. 2014. Is rainfed agriculture really a pathway from poverty? Agricultural Systems 123: 84-96.

Ifejika Speranza, C. 2006. Gender-Based Analysis of Vulnerability to Drought among Agro-Pastoral Households in Semi-Arid Makueni District, Kenya. In Gender and Sustainable Development: Case Studies from NCCR North-South, ed. S. Premchander and C. Muller. Geographica Bernensia: Bern.

Ikamari, L.D.E. 2005. The effect of education on the timing of marriage in Kenya. Demographic Research 12: 1-28.

Jayne, T.S., J. Chamberlin, and D.D. Headey. 2014. Land pressures, the evolution of farming systems, and development strategies in Africa: A synthesis. Food Policy 48: 1-17.

Kabeer, N. 1999. Resources, Agency, Achievements: Reflections on the Measurement of Women's Empowerment. Development and Change 30: 435-464.

Kenya Food Security Steering Group. 2019. The 2019 Long Rains Season Assessment report. Nairobi: Kenya Food Security Steering Group.

Kenya National Bureau of Statistics. 2019. Kenya Populaiton and Housing Census 2019. Nairobi: Kenya National Bureau of Statistics.

Lynam, T., and C. Fletcher. 2015. Sensemaking: A complexity perspective. Ecology and Society 20 (1): 65.

Mausch, K., D. Harris, L. Dilley, M. Crossland, T. Pagella, J. Yim, and E. Jones. (this issue). Not all about farming: capturing aspirations can be a challenge to rural development assumptions. European Journal of Development Research.

Mausch, K., D. Harris, E. Heather, E. Jones, J. Yim, and M. Hauser. 2018. Households' aspirations for rural development through agriculture. Outlook on Agriculture 47 (2): 108-115.

Meinzen-Dick, R., A. Quisumbing, J. Behrman, P. Biermayr-Jenzano, V. Wilde, M. Noordeloos, C. Ragasa, and N. Beintema. 2012. Engendering Agricultural Research, Development, and Extension. Washington, DC: International Food Policy; Research Institute (IFPRI).

Mercandalli, S., B. Losch, M.N. Belebema, J. Bélières, R. Bourgeois, M. Dinbabo, S. Fréguin-Gresh, C. Mensah, and C. Nshimbi. 2020. Rural Migration in sub-Saharan Africa: Patterns, Drivers and Relation to Structural Transformation. Rome: Food and Agricultural Organisation.

Musangi, P. 2017. Women land and property rights in Kenya. In: Annual World Bank Conference on Land and Poverty. Washington, DC.

Mwangi, M., and S. Kariuki. 2015. Factors determining adoption of new agricultural technology by smallholder farmers in developing countries. Journal of Economics and Sustainable Development 6 (5): 208-214.

Nelson, N. 1992. Rural-urban migration in central \& western Kenya. In Gender and Migration in Developing Countries, ed. S. Chant. London: Belhaven Press.

Nyasimi, M., and S. Huyer. 2017. Background: The gender gap in agriculture under a changing climate. Agriculture for Development 30: 37-40.

Petesch, P., R. Bullock, S. Feldman, L. Badstue, A. Rietveld, W. Bauchspies, A. Kamanzi, A. Tegbaru, and J. Yila. 2018. Local normative climate shaping agency and agricultural livelihoods in sub-Saharan Africa. Journal of Gender, Agriculture and Food Security 3 (1): 108-130. 
Pingali, P., K. Stamoulis, and R. Stringer. 2006. Eradicating Extreme Poverty and Hunger: Towards a Coherent Policy Agenda. ESA Working Paper No. 06-01. Rome: Food and Agriculture Organization.

QSR International. 2015. NVivo 11. Doncaster: QSR International Pty Ltd.

Rietveld, A. 2017. Gender norms and agricultural innovation; insights from Uganda. In Sustainable Intensification in Smallholder Agriculture; An Integrated Systems Research Approach, ed. I. Oborn, B. Vanlauwe, M. Phillips, R. Thomas, W. Brooijmans, and K. Atta-krah. London: Routledge.

Rietveld, A., M. Van Der Burg, and J. Groot. 2020. Bridging youth and gender studies to analyse rural young women and men's livelihood pathways in Central Uganda. Journal of Rural Studies 79: 152-163.

Saha, S., R. Goswami, and S.K. Paul. 2018. Recursive male out-migration and the consequences at source: A systematic review with special reference to the left-behind women. Space and Culture, India 5 (3): 30-53.

Shibata, R., S. Cardey, and P. Dorward. 2020. Gendered Intra-household Decision-Making Dynamics in Agriculutral Innovation Processes: Assets, Norms and Bargaining. Journal of International Development 32 (7): 1101-1125.

Slavchevska, V., S. Kaaria, and S. Taivalmaa. 2016. Feminization of Agriculture in the Context of Rural Transformations: What is the Evidence? Washington, DC: World Bank.

Sumberg, J., N.A. Anyidoho, J. Leavy, D.J.H. te Lintelo, and K. Wellard. 2012. Introduction: The Young People and Agriculture 'Problem' in Africa. IDS Bulletin. Oxford: Blackwell Publishing.

Sumberg, J., and C. Okali. 2013. Youth and economic opportunities. Innovations 12-13: 267-277.

Thornton, P.K., P. Kristjanson, W. Förch, C. Barahona, L. Cramer, and S. Pradhan. 2018. Is agricultural adaptation to global change in lower-income countries on track to meet the future food production challenge? Global Environmental Change 52: 37-48.

Tiffen, M., M. Mortimore, and F. Gichuki. 1995. More People, Less Erosion: Environmental Recovery in Kenya. Transactions of the Institute of British Geographers (Vol. 20).

Van den Broeck, G., and T. Kilic. 2019. Dynamics of off-farm employment in Sub-Saharan Africa: A gender perspective. World Development 119: 81-99.

Verkaart, S., K. Mausch, and D. Harris. 2018. Who are those people we call farmers? Rural Kenyan aspirations and realities. Development in Practice 28 (4): 468-479.

Vorley, B., L. Cotula, and M. Chan. 2012. Tipping the Balance: Policies to shape agricultural investments and markets in favour of small-scale farmers. Sustainable Urban Planning: Tipping the Balance. Oxford: Oxfam International.

Walker, T., and J. Alwang. 2015. Crop improvement, adoption, and impact of improved varieties in food crops in sub-Saharan Africa. Boston, MA: CABI.

World Agroforestry. 2020. Restoration of degraded land for food security and poverty reduction in East Africa and the Sahel: taking successes in land restoration to scale. http://www.worldagroforest ry.org/project/restoration-degraded-land-food-security-and-poverty-reduction-east-africa-and-sahel -taking. Accessed 22 Aug 2020.

Yabiku, S.T., V. Agadjanian, and A. Sevoyan. 2010. Husbands' labour migration and wives' autonomy, Mozambique 2000-2006. Population Studies 64 (3): 293-306.

Publisher's Note Springer Nature remains neutral with regard to jurisdictional claims in published maps and institutional affiliations. 